\title{
Viral Hepatitis C during a Screening Campaign in General Population of Benin: Seroprevalence and Associated Factors
}

\author{
Moussiliou Noel Paraiso ${ }^{*}\left(\mathbb{D}\right.$, Aboudou Raïmi Kpossou ${ }^{2,3}$, Comlan N'dehougbèa Sokpon ${ }^{3}$, \\ Hervé Lawin1, Cédric Bigot², Rodolph Koffi Vignon²,3, René Keke² \\ ${ }^{1}$ Regional Institute of Public Health, Ouidah, Benin \\ ${ }^{2}$ Faculty of Health Sciences, University of Abomey-Calavi, Abomey-Calavi, Benin \\ ${ }^{3}$ National and University Hsopital Hubert Koutoukou Maga of Cotonou, Cotonou, Benin \\ Email: *mparaiso@irsp-ouidah.org
}

How to cite this paper: Paraiso, M.N., Kpossou, A.R., Sokpon, C.N., Lawin, H., Bigot, C., Vignon, R.K. and Keke, R. (2021) Viral Hepatitis C during a Screening Campaign in General Population of Benin: Seroprevalence and Associated Factors. Open Journal of Epidemiology, 11, 178-188. https://doi.org/10.4236/ojepi.2021.112016

Received: March 5, 2021

Accepted: May 25, 2021

Published: May 28, 2021

Copyright $\odot 2021$ by author(s) and Scientific Research Publishing Inc. This work is licensed under the Creative Commons Attribution International License (CC BY 4.0).

http://creativecommons.org/licenses/by/4.0/

(c) (i) Open Access

\begin{abstract}
Introduction: Hepatitis $\mathrm{C}$ is a global public health problem. The purpose of this study was to determine the prevalence and factors associated with hepatitis $\mathrm{C}$ virus (HCV) antibody carriage during mass screening in several localities throughout Benin. Methods: This was a descriptive and analytical cross-sectional study with prospective data collection. This collection took place from 20 to 28 July 2019 at a free voluntary hepatitis C screening organized in Benin by Rotary Clubs in 23 sites throughout the country. A rapid diagnostic orientation test was used for the detection of anti-HCV antibodies. Results: A total of 9035 voluntary participants were included, mostly of Beninese nationality (99.0\%), with a median age of 27 years, of whom $51.1 \%$ $(4619 / 9035)$ were single and mainly schoolchildren, pupils or students (37.9\%; 3426/9035). HCV seroprevalence was 1.0\% (87/9035) [95\% CI $=0.8 \%$ - 1.2\%]. This infection was associated with age greater than 42 years $(\mathrm{ORa}=$ 2.71; 95\% CI: $1.06-6.95), \mathrm{p}<0.03$, and history of diabetes (ORa $=3.9 ; 95 \%$ CI: 1.9 - 7.6). Conclusion: HCV antibody seroprevalence is relatively low in the study population: $1 \%$. Factors associated with HCV antibody carriage were age, occupation and diabetic history.
\end{abstract}

\section{Keywords}

Hepatitis C Virus, Epidemiological Profile, Benin

\section{Introduction}

Hepatitis $\mathrm{C}$ is a liver inflammation caused by a hepatitis $\mathrm{C}$ virus (HCV). This virus 
causes acute hepatitis that evolves in majority (85\%) into chronic hepatitis [1] [2]. Chronic hepatitis $\mathrm{C}$ is one of the main causes of cirrhosis and primary liver cancer.

$\mathrm{HCV}$ is a virus that is mainly parenterally transmitted (transmitted through blood): the infection is most frequently caused by exposure to small amounts of blood, which may occur during drug injection, risky care or injection practices, transfusion of blood or blood products that have not undergone screening, or even during sexual practices resulting in exposure to blood [3] [4].

The disease caused by HCV is a major public health problem. Globally, the World Health Organization (WHO) estimates that 71 million people (1\%) are chronic carriers of hepatitis C [5]. According to WHO, in 2015 there were probably 1.75 million new infections with $\mathrm{HCV}$ worldwide (i.e., 23.7 new infections per 100,000 inhabitants). WHO estimates that in 2016, about 399,000 people died from hepatitis $\mathrm{C}$, most often following cirrhosis or primary liver cancer. Hepatitis $\mathrm{C}$ is a ubiquitous condition. However, the most affected regions are the Eastern Mediterranean region and the European region, with an estimated prevalence in 2015 of $2.3 \%$ and 1.5\%, respectively [6]. In Africa, Egypt and Cameroon are high prevalence countries for HCV [5].

In Benin, although national prevalence is unknown, it was estimated at $4.12 \%$ based on a 2013 survey among new blood donors [7]. Higher prevalence has been reported in some populations: $20 \%$ in sickle cell patients [8] and $7.6 \%$ in army recruits [9]. According to a study at the department of Hepato-gastroenterology of the National and University Hospital Hubert Koutoukou Maga in Cotonou, hepatitis C mostly affects people over 60 years of age (62.7\%), with a slight female predominance (54.2\%) [10].

Treatment with direct-acting antivirals (DAA) can cure more than $95 \%$ of people infected with $\mathrm{HCV}$, reducing the risk of death by cirrhosis or hepatic cancer; but access to diagnosis and treatment is still limited in low-income countries like Benin. There currently is no vaccine available against hepatitis $\mathrm{C}$.

Hepatitis $\mathrm{C}$, either acute or chronic, remains a silent disease, often asymptomatic, usually revealed by the onset of complications [11]. Early diagnosis of $\mathrm{HCV}$ can prevent complications resulting from the infection and transmission of the virus. WHO recommends screening for $\mathrm{HCV}$ in people at an increased risk of infection.

To support countries working toward global hepatitis elimination goals under the 2030 Agenda for Sustainable Development, WHO has promoted awareness of the infection. As part of World Hepatitis Day 2019, the theme was: "Invest in eliminating hepatitis." This was how Rotary Clubs of Benin engaged to support Rotary International in the fight against hepatitis, a noble fight for people's well-being, and to participate in the pan-African week against hepatitis. Thus, a free screening campaign for viral hepatitis $\mathrm{B}$ and $\mathrm{C}$ was organized in various localities of Benin, to assess the spread of the infection, and to plan actions in order to achieve zero cases of hepatitis in Benin.

We therefore took this opportunity to identify the current epidemiologic pro- 
file of hepatitis C in Benin.

\section{Methods}

\subsection{Study Design}

This is a descriptive and analytical cross-sectional study, with prospective data collection.

\subsection{Context}

Data for this study comes from voluntary screening of men and women of all ages, organized by Rotary Clubs of Benin. Data collection took place from July 20 to 28 , 2019. It was an International Service activity of all Rotary clubs around the world. It was part of Rotary International's second strategic focus, namely: prevention and treatment of diseases. The action focused specifically on voluntary screening for hepatitis B and C in a framework entitled: Zero Hepatitis, Benin.

\subsection{Data Collection}

Data collection required a preexisting list of sites, spread in one or many screening stations (see Figure 1). Each club (26 in total in Benin) designated a focal point or manager of a screening station. This focal point was in charge of a screening team by station, made of three volunteers and three health agents. The team functioned according to a pre-established procedure, made available to them.

\subsection{Minimum Material Required}

Each station was equipped with a registration book adequately filled in according to the practical guidelines for managing a screening station, with data such as: name of registration book filler, order number, first and last names of the volunteer and his/her phone number, occupation, age, past exposure to risk, hepatitis B or C screening test result. One of the volunteers should have an Android mobile phone with the Kobocollect application installed, which allowed data to be entered onsite, while respecting participant's anonymity.

In addition to the screening kits, available at each station were: medical supplies (alcohol, gloves, lancets for fingertip pricking), a safety box, and a garbage bag. All books used at each station were returned to the national Zero Hepatitis comity. Results sheets were also available. The focal point reported daily on the number of screening kits used. For hepatitis $\mathrm{C}$ screening, the rapid diagnostic orientation test (RDOT) used was InTec HCV Rapid Test ${ }^{\circledR}$ (InTec Products. Inc., China).

\subsection{Procedure for Screening Participants}

At least two volunteers oversaw welcoming and registering the participant in the registration book for tracing. To be recorded were the participant order number 
and phone number. With a pre-filled results sheet, the participant then went to the first health agent for a pretest counseling session. Afterwards, the participant was screened by the second health agent, who took the results sheet, and followed required procedure.

The screening result was added to the results sheet by the second health agent, who in turn gave it to the third health agent. Next to this agent was the volunteer who held the Android mobile phone to administer the questionnaire to the participant. In the end, screening result was given to participant by the health agent in charge of post-test counseling.

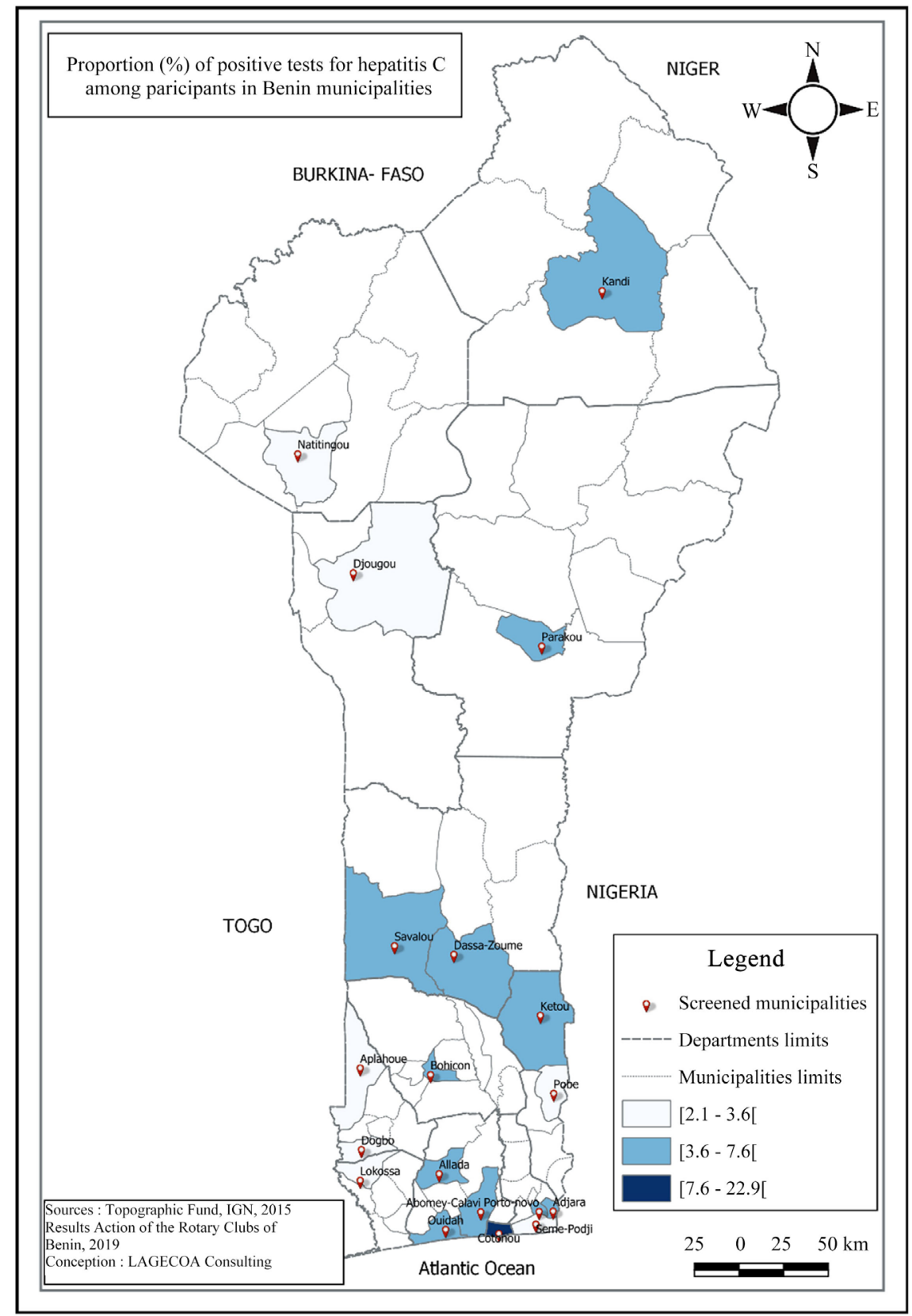

Figure 1. Communal distribution of hepatitis $\mathrm{C}$ rapid diagnostic test (RDT) volunteers in Benin: A 2019 Hepatitis Zero project of Benin Rotary Clubs $(n=9035)$. 


\section{Action steps based on screening result}

When the test was positive, the subject was notified by a health agent who was a screening team member. The participant was reassured to be contacted by the national program fighting against hepatitis for confirmation tests and care management.

When the test was negative, the patient was reassured not to have HBV or $\mathrm{HCV}$ infection. Adequate counseling on how to prevent infection was provided.

\subsection{Data Management and Analysis}

Data generated from this screening have allowed to factor in variables such as: age, sex, occupation, education level, place of residence, history of contact with blood (transfusion, scarification), and non-communicable disease (diabetes). This data was exported from the Kobocollect application to the Stata software for analysis according to the following process: a description of participants' screening distribution by calculating the mean and standard deviation or the median with inter-quartile interval for the quantitative variables, followed by proportion calculation of the qualitative variables.

Bivariate data analysis was performed using Student's statistical test, and Pearson's Chi square.

This analysis allowed us to determine the associations between rapid test results and the independent variables. It also made it possible to measure the prevalence ratio (PR) and 95\% confidence interval. For the multivariate analysis, dummy variables were created for variables with categories greater than two. Likewise, some categories with very small numbers were merged when necessary.

Result from multivariate analysis was obtained through logistic regression modeling used to find factors adjusted by and associated with the hepatitis $\mathrm{C}$ test result. Variables with a p-value less than or equal to $20 \%$ during the univariate analysis were introduced into the initial logistic regression model after a top-down stepwise elimination. Factors retained in the final model were those with p-value less than 5\%. Model suitability was assessed with the Hosmer-Lemeshow test. The model is said to be adequate when the p-value is greater than $5 \%$.

\section{Results}

\subsection{Studied Population Characteristics}

In total, we obtained 9040 files from participants to hepatitis C RDOT, of which 9035 were used because five (05) files contained erroneous data. Files came from 23 screening stations across the country (see Table 1). About one in four participants $(23 \%)$ were screened in the Littoral department, the only multi-site department (5 sites); respectively $18.1 \%$ and $13.3 \%$ came from the Atlantique and Ouémé departments. Most participants were of Beninese nationality (99.0\%), males $(51.6 \%)$ with a median age of 27 years (interquartile range $=25$ years). 
M. N. Paraiso et al.

Table 1. Factors associated with hepatitis C prevalence (PR) among participants in rapid diagnostic test $(R D T)$ in $2019(n=9035)$.

\begin{tabular}{|c|c|c|c|c|c|c|}
\hline & \multicolumn{2}{|c|}{ Positif Test } & \multirow{2}{*}{$\frac{\text { Negatif Test }}{\mathrm{n}}$} & \multirow{2}{*}{ PR } & \multirow{2}{*}{$95 \% \mathrm{CI}$} & \multirow{2}{*}{$\mathrm{p}$} \\
\hline & $\mathbf{n}$ & $\%$ & & & & \\
\hline \multicolumn{7}{|l|}{ Gender } \\
\hline Male $(\mathrm{n}=4664)$ & 47 & 54.0 & 4617 & 1.1 & $0.7-1.7$ & 0.65 \\
\hline Female $(n=4371)$ & 40 & 46.0 & 4331 & 1 & & \\
\hline \multicolumn{7}{|l|}{ Age group (in years) } \\
\hline Less than $17(\mathrm{n}=2380)$ & 20 & 23.0 & 2360 & 1 & & \\
\hline 17 to $27(\mathrm{n}=2260)$ & 7 & 8.0 & 2253 & 0.4 & $0.2-0.9$ & 0.02 \\
\hline 28 to $41(\mathrm{n}=2214)$ & 12 & 13.8 & 2202 & 0.6 & $0.3-1.3$ & 0.22 \\
\hline 42 and over $(n=2181)$ & 48 & 55.2 & 2133 & 2.7 & $1.6-4.5$ & 0.0001 \\
\hline \multicolumn{7}{|l|}{ Marital status } \\
\hline Single $(\mathrm{n}=4619)$ & 28 & 32.2 & 4591 & 1 & & \\
\hline Divorced/widowed $(\mathrm{n}=353)$ & 10 & 11.5 & 343 & 4.8 & $2.3-9.9$ & 0.000 \\
\hline In couple/married $(\mathrm{n}=4063)$ & 49 & 56.3 & 4014 & 2.0 & $1.2-3.2$ & 0.004 \\
\hline \multicolumn{7}{|l|}{ Education level } \\
\hline Non-schooled $(\mathrm{n}=1118)$ & 9 & 10.3 & 1109 & 0.9 & $0.4-2.1$ & 0.88 \\
\hline Elementary $(n=2053)$ & 26 & 29.9 & 2027 & 1.5 & $0.8-2.6$ & 0.17 \\
\hline Secondary $(\mathrm{n}=3285)$ & 30 & 34.5 & 3255 & 1.1 & $0.6-1.9$ & 0.80 \\
\hline College/university $(\mathrm{n}=2579)$ & 22 & 25.3 & 2557 & 1 & & \\
\hline \multicolumn{7}{|l|}{ Occupation group } \\
\hline Schoolchildren/pupils/students $(\mathrm{n}=3426)$ & 23 & 26.4 & 3403 & 0.5 & $0.3-0.8$ & 0.008 \\
\hline Unemployed/housewives $(\mathrm{n}=657)$ & 10 & 11.5 & 647 & 1.1 & $0.5-2.3$ & 0.87 \\
\hline Craftsmen/laborers $(\mathrm{n}=1005)$ & 14 & 16.1 & 991 & 0.9 & $0.5-1.9$ & 0.93 \\
\hline Dealers/traders $(\mathrm{n}=841)$ & 5 & 5.7 & 836 & 0.4 & $0.2-1.1$ & 0.06 \\
\hline Workers, public/private sector $(\mathrm{n}=1608)$ & 23 & 26.4 & 1585 & 1 & & \\
\hline Retired/others $(\mathrm{n}=1498)$ & 12 & 13.8 & 1486 & 0.6 & $0.3-1.1$ & 0.09 \\
\hline \multicolumn{7}{|l|}{ Diabetic } \\
\hline Yes $(n=223)$ & 11 & 12.6 & 212 & 5.9 & $3.1-11.4$ & 0.0000 \\
\hline No $(\mathrm{n}=8812)$ & 76 & 87.4 & 8736 & 1 & & \\
\hline \multicolumn{7}{|l|}{ History of blood transfusion } \\
\hline Yes $(\mathrm{n}=394)$ & 6 & 6.9 & 388 & 1.6 & $0.7-3.8$ & 0.24 \\
\hline No $(n=8641)$ & 81 & 93.1 & 8560 & 1 & & \\
\hline \multicolumn{7}{|l|}{ History of scarification } \\
\hline Yes $(\mathrm{n}=2428)$ & 30 & 34.5 & 2398 & 1.4 & $0.9-2.2$ & 0.10 \\
\hline No $(n=6607)$ & 57 & 65.5 & 6550 & 1 & & \\
\hline \multicolumn{7}{|l|}{ History of hepatitis B } \\
\hline Yes $(\mathrm{n}=333)$ & 3 & 3.4 & 330 & 0.9 & $0.3-2.9$ & 0.91 \\
\hline No $(n=8702)$ & 84 & 96.6 & 8618 & 1 & & \\
\hline
\end{tabular}

PR: prevalence ratio. 
The proportion of those born before 2002, year when the hepatitis B vaccine was introduced, was $22.7 \%$. More than half (51.1\%) of the participants were single, and less than one in three participants (29.7\%) were married. Participants were mainly schoolchildren, pupils, or students $(37.9 \%)$, public or private sector workers $(17.8 \%)$, and craftsmen or laborers $(11.1 \%)$. About $2.5 \%$ of the participants reported having diabetes, while a history of hepatitis B was observed in $3.7 \%$ of the participants. Besides, a history of blood transfusion and scarification was recorded in $4.4 \%$ and $26.9 \%$ of the participants respectively.

\subsection{Anti-HCV Antibodies Seroprevalence}

According to the hepatitis C RDOT results, participants who tested positive were 87 of the 9035 , a prevalence of $1.0 \%$ [95\% CI $=0.8 \%-1.2 \%$ ].

\subsection{Factors Associated with Anti-HCV Antibodies Carriage}

Univariate analysis shows that the prevalence of a positive hepatitis C RDOT was not significantly different by gender $(\mathrm{p}=0.65)$, blood transfusion history $(0.24)$, and hepatitis B history (0.91). In contrast, the mean age of participants who tested positive ( 41.3 years \pm 22.7 years) was significantly higher $(\mathrm{p}<0.001)$ than that of those who tested negative (29.2 years \pm 17.4 years). Of the 87 participants who tested positive to $\mathrm{HCV}, 23.0 \%$ were under 18 years of age. The prevalence ratio showed that the difference is not significant with the other groups over the age of $18(\mathrm{p}=0.28)$. The proportion of participants who tested positive was significantly higher in divorced/widowed $(\mathrm{p}=0.000)$ and couple/married $(\mathrm{p}=0.004)$ individuals compared to singles. The prevalence of the positive test was significantly higher in diabetics than in non-diabetics $(\mathrm{p}=0.000)$.

From the univariate analysis, potential factors associated with hepatitis $\mathrm{C}$ infection were age, marital status, level of education, occupation, and history of diabetes and scarification.

Multivariate analysis found three associated factors in the final model: age, occupation and history of diabetes (see Table 2). Considering age and occupation, diabetic participants were at four times (ORa $=3.9$; 95\% CI: $1.9-7.6)$ higher risk for hepatitis $C$ than those without a history of diabetes. Participants aged 42 and over were three times (ORa $=2.7 ; 95 \%$ CI: $1.1-6.9$ ) more at risk of suffering from hepatitis than those under 17 years, and those in the age group 17 to 27 years were three times $(\mathrm{ORa}=0.3 ; 95 \% \mathrm{CI}: 0.1-0.8)$ less at risk than those 42 and over, with known diabetic status and occupation. Knowing age and diabetic status, schoolchildren, pupils and students were three times (ORa $=0.3 ; 95 \% \mathrm{CI}$ : 0.1 - 0.9) more at risk of suffering from hepatitis $C$ than workers (public/private sectors).

\section{Discussion}

This study estimated the seroprevalence of hepatitis C in Benin, and identified factors associated with this infection. To our knowledge, this is the first national study on this infection. 
Table 2. Logistic regression model. Multivariate analysis of factors associated with the occurrence of hepatitis C among participants in rapid diagnostic test in Benin in 2019, (n $=9035)$.

\begin{tabular}{cccc}
\hline Variables & PRadj & $95 \%$ CI & p \\
\hline Diabetic & & & \\
\hline Yes & 3.88 & $1.98-7.62$ & 0.00 \\
No & 1 & & \\
\hline Age group (by quartiles) & & & \\
\hline Less than 17 & 1 & & 0.02 \\
17 to 27 & 0.35 & $0.15-0.86$ & 0.50 \\
42 and over 41 & 0.71 & $0.25-1.95$ & 0.03 \\
\hline Occupational group & 2.71 & $1.06-6.95$ & \\
\hline Schoolchildren/pupils/students $(\mathrm{n}=3426)$ & 1 & & 0.96 \\
Unemployed/housewives $(\mathrm{n}=657)$ & 1.02 & $0.38-2.73$ & 0.87 \\
Craftsmen/laborers (n $=1005)$ & 0.94 & $0.44-2.00$ & 0.72 \\
Dealers/traders (n $=841)$ & 1.13 & $0.57-2.23$ & 0.04 \\
Workers, public/private sector $(\mathrm{n}=1608)$ & 0.36 & $0.14-0.95$ & 0.17 \\
Retired/others (n $=1498)$ & 0.60 & $0.29-1.24$ & \\
\hline
\end{tabular}

Hosmer-Lemes how Test: Khi2 $=10.21 \mathrm{p}=0.18$, PRadj: adjusted prevalence ratio.

Based on the study findings, seroprevalence of hepatitis C in Benin is $1.0 \%$. This prevalence is about the same as that found by Aboubacar et al. (1.2\%) in a study on pregnant women in 2020 [12]. In 2015, Petruzziello et al. [13] estimated the prevalence of hepatitis $\mathrm{C}$ in Benin at 1.6\%. The observed difference in these findings may be due to the fact that Petruzziello et al.'s estimation was based on literature review data between 2000 and 2015.

This study found that individuals with a history of diabetes were at higher risk for hepatitis C. Many studies, including Sanae et al. in Morocco [14] and Diarra et al. in Mali [15] have reached the same conclusion. This high prevalence among diabetics can be explained by frequent recourse to hospital care, particularly by injection in this population. This reveals the importance of routine hepatitis $\mathrm{C}$ screening in people with diabetes. Implementing this measure would prevent late diagnosis of this comorbidity, whose rapid management would improve patient's condition.

People over the age of 42 years have twice as likely to have hepatitis $\mathrm{C}$ as young people under the age of 17 . This result is consistent with several other research conducted around the world, in countries such as Ethiopia and Iran [16] [17]. This high prevalence among older persons may be explained by the fact that this group has been more exposed to practices favorable to this viral infection, such as scarification and tattoos with multiple use material. In addition, blood transfusion, surgery, hemodialysis or difficult childbirth, as well as certain 
injections (lack of asepsis in care, reuse of needles) before 1992 were associated with a risk of $\mathrm{C}$ virus infection because of the limited knowledge of the virus and its mode of transmission at that time.

Although history of scarification was not significant after adjusting for age, history of diabetes and occupation, it is worth noting an association between scarification and the presence of hepatitis C virus. In Rwanda, Makuza et al. [17] found similar results from their work. Although the practice of scarification is in decline, it is important to recognize its influence on hepatitis $C$ prevalence in order to sustain ongoing actions for its complete elimination in communities. Involving religious leaders in strategies implemented for behavior change is a real asset for achieving this goal.

Contrary to findings by Makuza et al., marital status was not significantly associated with hepatitis $\mathrm{C}$ infection in our multivariate model. However, this association was significant on the univariate analysis, stipulating that married, divorced or widowed were at higher risk than single people, confirming the trend found by Makuza et al. in 2019 [18].

The main limitation to this study is sampling, as it involved voluntary participants to screening throughout the country. Because screening stations were often housed in universities or schools, the study included a majority of learners, which could be a recruitment bias. Study findings may not be generalizable, since participants selection was not random. In addition, positive rapid test results were not routinely confirmed by Ezyme Linked Immuno-Sorbent-Assay (ELISA) or polymerase chain reaction (PCR) and therefore the prevalence found could have been an overestimate due to possible false positives or cured HCV patients. Further studies are needed to confirm these preliminary data on a national scale.

\section{Conclusion}

Seroprevalence of HCV antibodies is $1 \%$ in the study population. HCV infection appears to affect older people (over the age of 42), diabetics, schoolchildren, pupils and students. However, since the study involved voluntary participants for screening, findings should be confirmed through a national study involving random sampling, in order to better understand the spread of hepatitis $\mathrm{C}$ in Benin.

\section{Acknowledgements}

We acknowledge the 26 Rotary Clubs of Benin who were able to mobilize resources for the realization and success of Rotary International's Zero Hepatitis action. We do not forget all the volunteers and participants who contributed.

\section{Conflicts of Interest}

The authors declare no conflicts of interest regarding the publication of this paper. 


\section{References}

[1] Lejeune, O. (2006) La maladie. In: Trépo, C., Merle, P. and Zoulim, F., Eds., Hépatites virales $B$ et $C$, John Libbey Eurotext, Paris, 149-161.

[2] Shepard, C.W, Finelli, L. and Alter, M.J. (2005) Global Epidemiology of Hepatitis C Virus Infection. The Lancet Infectious Diseases, 5, 558-567. https://doi.org/10.1016/S1473-3099(05)70216-4

[3] Ansaldi, F., Orsi, A., Sticchi, L., Bruzzone, B. and Icardi, G. (2014) Hepatitis C Virus in the New Era: Perspectives in Epidemiology, Prevention, Diagnostics and Predictors of Response to Therapy. World Gastroenterology Journal, 20, 9633-9652. https://doi.org/10.3748/wjg.v20.i29.9633

[4] Pradat, P. (2006) Epidémiologie et santé publique: Une pandémie émergente. In: Editor, Hépatites virales $B$ et $C$, John Libbey Eurotext, Paris, 115-123.

[5] World Health Organization (2017) Global Hepatitis Report. http://apps.who.int/iris/bitstream/10665/255016/1/9789241565455-eng.pdf?ua=1

[6] World Health Organization (2020) Principaux repères sur l'hépatite C. https://www.who.int/fr/news-room/fact-sheets/detail/hepatitis-c

[7] Kodjoh, N. (2015) Fighting Viral Hepatitis B and C in Africa Focus on Benin. Médecine et Santé Tropicales, 25, 141-144. https://doi.org/10.1684/mst.2015.0439

[8] Kodjoh, N., Bigot, A., Avode, G., Houngbe, F., Attolou, V., Tonato, S., et al. (1996) Prevalence des anticorps anti-vhc chez les malades drepanocytaires polytransfusés a cotonou (BÉNIN). Médecine d Afrique Noire, 43, 466-467.

[9] Sehonou, J., Atadokpede, F., Abdoulaye, I., Kodjoh, N. and Zohoun, I. (2007) Séroprévalence des anticorps antivirus de l'hépatite $\mathrm{C}$ dans une population de jeunes recrues au Bénin. Journal Africain d Hépato-Gastroentérologie, 1, 103-105. https://doi.org/10.1007/s12157-007-0025-6

[10] Kpossou, A.R., Séhonou, J., Sokpon, C.N.M., Mouzouvi, C.R.A. and Vignon, K.R. (2019) Hepatite $c$ en republique du benin: Revue actualisee sur les aspects epidemiologiques, clinico-biologiques et therapeutiques. Journal de la Société de Biologie Clinique du Bénin, No. 32, 27-30.

[11] Moosavy, S.H., Davoodian, P., Nazarnezhad, M.A., Nejatizaheh, A., Eftekhar, E., Mahboobi, H. (2017) Epidemiology, Transmission, Diagnosis, and Outcome of Hepatitis C Virus Infection. Electron Physician, 9, 5646-5656.

http://doi.org/10.19082/5646

[12] Aboubakar, M., Kpossou, A.R., Glago, B.R.G.H., Aguiah, A.G., Mboreha, Z.H. and Sehonou, J. (2020) Prévalence et facteurs associés au portage des anticorps anti-VHC chez des femmes enceintes à Cotonou. The Pan African Medical Journal, 36, Article No. 182. https://doi.org/10.11604/pamj.2020.36.182.23122 https://www.panafrican-med-journal.com/content/article/36/182/full/

[13] Petruzziello, A., Marigliano, S., Loquercio, G., Cozzolino, A. and Cacciapuoti, C. (2016) Global Epidemiology of Hepatitis C Virus Infection: An Update of the Distribution and Circulation of Hepatitis C Virus Genotypes. World Gastroenterology Journal, 22, 7824-7840. https://doi.org/10.3748/wjg.v22.i34.7824

[14] Sanae, E., Zakaria, C., Abainou, L., Nassifa, B., Saïd, K., Hassan, Q., et al. (2017) Hepatite $\mathrm{c}$ et diabete type ii. International Journal of Advanced Research, 5, 935-939. https://doi.org/10.21474/IJAR01/4799

[15] Diarra, M.T., Konaté, A., Diakité, Y., Doumbia Samaké, K., Sow Coulibaly, H., Kassambra, Y., et al. (2013) Infection par le virus de l'hépatite C chez les patients diabétiques traités au CHU Gabriel Touré et au Centre de lutte contre le diabète de 
Bamako (Mali). Journal Africain d Hépato-Gastroentérologie, 7, 188-191.

https://doi.org/10.1007/s12157-013-0487-7

[16] Ameha, Z., Tadesse, S., Assefa, A. and Tessema, B. (2019) Prevalence and Associated Factors of Hepatitis C Virus and Human Immunodeficiency Virus Infections among Voluntary Counseling and Testing Clients Attending Private Health Facilities in Bahir Dar city, North West Ethiopia 2014. BMC Research Notes, 12, Article No. 693. https://doi.org/10.1186/s13104-019-4727-9 https://bmcresnotes.biomedcentral.com/articles/10.1186/s13104-019-4727-9

[17] Taherkhani, R. and Farshadpour, F. (2015) Epidemiology of Hepatitis C Virus in Iran. World Gastroenterology Journal, 21, 10790-10810.

https://doi.org/10.3748/wjg.v21.i38.10790

[18] Makuza, J.D., Liu, C.Y., Ntihabose, C.K., Dushimiyimana, D., Umuraza, S., Nisingizwe, M.P., et al. (2019) Risk Factors for Viral Hepatitis C Infection in Rwanda: Results from a Nationwide Screening Program. BMC Infectious Diseases, 19, Article No. 688. https://doi.org/10.1186/s12879-019-4322-7 https://bmcinfectdis.biomedcentral.com/articles/10.1186/s12879-019-4322-7 